\title{
Generation of Virus Free Potato Plantlets through Meristem Culture and Their Field Evaluation
}

\section{Md. Abul Kalam Azad1*, Zubaida Khatun', Touria El-Jaoual Eaton², Md. Isrfil Hossen1, Md. Kamrul Haque1, Edward Binod Soren'}

\author{
${ }^{1}$ Department of Crop Science \& Technology, Rajshahi University, Rajshahi, Bangladesh \\ ${ }^{2}$ Cooperative Extension and Research, Lincoln University of Missouri, Jefferson, USA \\ Email: ^azad.adrinwa@gmail.com
}

How to cite this paper: Azad, Md.A.K., Khatun, Z., El-Jaoual Eaton, T., Hossen, Md.I., Haque, Md.K. and Soren, E.B. (2020) Generation of Virus Free Potato Plantlets through Meristem Culture and Their Field Evaluation. American Journal of Plant Sciences, 11, 1827-1846.

https://doi.org/10.4236/ajps.2020.1111131

Received: October 9, 2020

Accepted: November 27, 2020

Published: November 30, 2020

Copyright $\odot 2020$ by author(s) and Scientific Research Publishing Inc. This work is licensed under the Creative Commons Attribution International License (CC BY 4.0).

http://creativecommons.org/licenses/by/4.0/

\begin{abstract}
Different aspects of micropropagation through meristem culture for the production of virus indexed source plants, in vitro tuberization and field evaluation of the in vitro regenerated plants were studied on four commercial cultivars of potato (Solanum tuberosum L.) viz., Diamant, Cardinal, Shilbilati and Lalpakri. The investigation was conducted at Rajshahi, Bangladesh from December 2010 to March 2012 to produce virus-free potato plantlets through meristem culture, shoot multiplications with root induction as well as their acclimatization and evaluation of morphological characters and tuber yield under field condition. Shoot tips of 25 - 30 day old field-grown plants of above mentioned four cultivars were used for meristem isolation. After isolation, meristems of these varieties of potato were cultured on " $M$ " shaped filter paper bridge in Murashige and Skoog (MS) liquid medium. Four different treatments of media formulations viz. $0.1 \mathrm{mg} / \mathrm{L} \mathrm{KIN}+0.1 \mathrm{mg} / \mathrm{L} \mathrm{GA}_{3}, 0.1$ $\mathrm{mg} / \mathrm{L} \mathrm{KIN}+0.5 \mathrm{mg} / \mathrm{L} \mathrm{GA}_{3}, 0.5 \mathrm{mg} / \mathrm{L} \mathrm{KIN}+0.1 \mathrm{mg} / \mathrm{L} \mathrm{GA}_{3}$ and $0.5 \mathrm{mg} / \mathrm{L} \mathrm{KIN} \mathrm{+}$ $0.5 \mathrm{mg} / \mathrm{L} \mathrm{GA}_{3}$ were used as plant growth regulators. From these formulations $\mathrm{MS}+0.1 \mathrm{mg} / \mathrm{L} \mathrm{KIN}+0.5 \mathrm{mg} / \mathrm{L} \mathrm{GA}_{3}$ was found to be the best for the primary establishment of meristem culture. The primarily established meristems were subcultured on to MS semisolid basal medium supplemented with four different treatment combinations of hormones viz. $0.5 \mathrm{mg} / \mathrm{L} \mathrm{BA}+1.0 \mathrm{mg} / \mathrm{L} \mathrm{IBA}$; $0.1 \mathrm{mg} / \mathrm{L} \mathrm{KIN}+0.1 \mathrm{mg} / \mathrm{L} \mathrm{GA}_{3} ; 0.5 \mathrm{mg} / \mathrm{L} \mathrm{BA}+0.5 \mathrm{mg} / \mathrm{L} \mathrm{GA}{ }_{3}$ and $0.5 \mathrm{mg} / \mathrm{L}$ $\mathrm{KIN}+0.5 \mathrm{mg} / \mathrm{L} \mathrm{GA}_{3}$ were used to identify the suitable media compositions for shoot proliferation. Results showed that out of these four media treatments the formulation $0.5 \mathrm{mg} / \mathrm{L} \mathrm{BA}+0.5 \mathrm{mg} / \mathrm{L} \mathrm{GA}_{3}$ was found to be the best suitable for shoot generation. Among the four cultivars of potato higher frequency of shoot proliferation (number of shoots/explant and longest shoot
\end{abstract}


length) was observed in Diamant, though the highest shoot formation (76\%) was recorded in Cardinal. Virus free in vitro grown potato plantlets were obtained through DAS-ELISA test and used substantially for micro-propagation. After gradual acclimatization of rooted plantlets of four potato cultivars, they were transferred into the field for cultivation and established successfully. It was observed from the field study of in vitro meristem-derived plantlets that there were no virus-affected plants. The virus-free exotic varieties were much superior in all vegetative attributes and yield compared to those of indigenous varieties with producing potato plants of normal height. In contrast, the indigenous varieties took a longer time to tuber initiation and maturity, lower plant height and number of leaves per plant, a higher number of tubers but a lower amount of tuber weight per plant, and poorer tuber grade than the exotic varieties. However, the variety Cardinal exposed the best performances in the context of survival percentage of plantlets (90\%), days to tuber initiation (DTI), a number of leaves per plant (NL), tuber weight per plant $(343.40 \%)$ and the percentage of rich tuber grade.

\section{Keywords}

Meristem Culture, Micropropagation, Potato Cultivars, Plantlets, Plant Growth Regulators

\section{Introduction}

Potato (Solanum tuberosum L.) is considered one of the most economically important vegetable crops of the world as well as in Bangladesh. It is recognized as every day used vegetable for Bangladeshi people and is substantially used to supplement food requirements in Bangladesh after two cereal rice and wheat. It is enriched with starch, protein, fat, iron, magnesium, potassium, phosphorus, sugar and vitamin C. Potato can be used for the production of high-quality starch, alcohol, glucose, pectin, Sugar and by the product of high-quality proteins and fodder [1]. It is the cheapest source of carbohydrates that is used as a supplementary diet to rice. As a food product potatoes are converted into potato chips, potato slices, French fries, etc. Potatoes are also a good source of minerals, at least 12 essential vitamins and extremely high content of vitamin C compare to other food crops [1]. It is mainly cultivated in winter season.

The average yield of potato in Bangladesh is 13.32 - 18.08 ton/ha [2] [3] which is very low in comparison to other potato producing countries like 43.2 tha-1 in France, 44.7 tha- 1 in Netherlands and 44.6 tha- 1 in the USA in 2007 [4]. Its production can be increased up to 30 - 40 ton/ha using high yielding varieties and improved production technology [5]. The causes of such low production and non-profitability of potato cultivation might be due to lack of quality seeds of good varieties, unavailability and uneven distribution of certified seeds, inadequate storage facilities, high production cost, and short growing season are 
noticeable [6]. Its productivity is also hampered due to the attack of a number of pests and diseases. The causal organisms of potato diseases include bacteria, fungi, viruses, viroids, mycoplasma and nematodes [7].

As a vegetative propagule, the potato tuber preserves not only the desirable genotype but also viruses and other tissue borne pathogens as well. However, once any part of a potato tuber is infected with a viral disease, the pathogen is transmitted from one generation to thereafter. There are approximately 23 viruses and virus like organisms that cause disease in potato. The occurrence of viral disease is an important reason for causing low yield of potato in different varieties [8]. To overcome this situation Bangladesh needs to produce a sufficient amount of virus free foundation and certified potato seeds to mitigate the demand of its increasing population. Potato is vegetatively propagated by means of tubers. Researchers have found some results to eliminate virus from potato tubers through meristem culture technique [9]. Meristem culture was the first tissue culture approach successfully applied to obtain virus-free potato stocks. In potatoes, through this technique the isolated plant segments like meristem or shoot tips, node, internodes, leaves, etc. are cultivated aseptically in vitro in some artificial nutrient medium viz. MS [10] medium under controlled conditions.

Due to farmer and consumer acceptability, particular attention should be given to the improvement of improving potato variety (IPV). The increase in the productivity of potatoes is related to disease-free quality seed. The objectives of this study are to produce virus free plantlets through meristem culture, shoot multiplications with root induction, evaluation of the in vitro regenerated plants with morphological characters and tuber yield under field condition. Therefore, it would be logical to undertake the present investigation applying the meristem culture technique for getting virus free plantlets to improve potato variety.

\section{Materials and Methods}

\subsection{Experimental Site, Planting Materials and Reagents}

The experiment was carried out in the Department of Crop Science and Technology, and Plant Breeding and Gene Engineering Laboratory under Rajshahi University and in the field of Shyampur, Katakhali, Rajshahi, Bangladesh during the period from December, 2010 to March, 2012. Two exotic potato varieties Diamant and Cardinal and two indigenous varieties Shilbilati and Lalpakri were used in the investigation collected from A. H. Z. BIOTEK SEEDS Ltd. nursery, Namo Bhadra, Rajshahi.

The plant growth regulators (PGR) such as indole-3-butyric acid (IBA) under auxin group; 6-benzyl aminopurin (BA) and 6-Furfuryl aminopurin (KIN) under cytokinin group; and Gibberellic acid-3 $\left(\mathrm{GA}_{3}\right)$ were used in this study. Generally $0.1 \% \mathrm{HgCl}_{2}$ was used as surface sterilizing agent, tween-20 (polyoxyethelene soribitan monolaurate) and savlon (Antiseptic, ACI Pharma, Bangladesh) were used as surfactant and detergent. MS medium was used for all kinds of in vitro experiments. 


\subsection{Treatments}

Different plant growth regulators (PGR) viz. auxin (IBA), cytokinin (BA and $\mathrm{KIN}$ ), and gibberellic acid at different concentrations were used in two dimensions for making different media combinations. For the primary establishment of meristems there involved four treatment combinations composed of KIN and $\mathrm{GA}_{3}$ at their various concentrations viz. $0.1 \mathrm{mg} / \mathrm{L} \mathrm{KIN}+0.1 \mathrm{mg} / \mathrm{L} \mathrm{GA}_{3}, 0.1 \mathrm{mg} / \mathrm{L}$ $\mathrm{KIN}+0.5 \mathrm{mg} / \mathrm{L} \mathrm{GA}_{3}, 0.5 \mathrm{mg} / \mathrm{L} \mathrm{KIN}+0.1 \mathrm{mg} / \mathrm{L} \mathrm{GA}_{3}$ and $0.5 \mathrm{mg} / \mathrm{L} \mathrm{KIN}+0.5$ $\mathrm{mg} / \mathrm{L} \mathrm{GA}_{3}$. After the establishment of primary meristems they were subcultured on to MS semisolid basal medium supplemented with IBA, BA, KIN and gibberellic acid in different combinations at various levels of concentrations formulated by four media treatments viz. $0.5 \mathrm{mg} / \mathrm{L} \mathrm{BA}+1.0 \mathrm{mg} / \mathrm{L} \mathrm{IBA} ; 0.1 \mathrm{mg} / \mathrm{L} \mathrm{KIN} \mathrm{+}$ $0.1 \mathrm{mg} / \mathrm{L} \mathrm{GA}_{3} ; 0.5 \mathrm{mg} / \mathrm{L} \mathrm{BA}+0.5 \mathrm{mg} / \mathrm{L} \mathrm{GA}_{3}$ and $0.5 \mathrm{mg} / \mathrm{L} \mathrm{KIN}+0.5 \mathrm{mg} / \mathrm{L} \mathrm{GA}_{3}$ were used to identify the suitable media compositions for shoot proliferation.

\subsection{Preparation of Culture Medium}

MS medium was used for all in vitro experiments which includes meristem culture, micropropagation of meristem derived plantlets, induction of microtuber etc. Sucrose was added at the rate of $30 \mathrm{~g} / \mathrm{L}$. According to requirements different growth regulators were supplemented to different media separately. Agar was added at the rate of $8-10 \mathrm{~g} / \mathrm{L}$ for the preparation of semi-solid medium. For primary meristem culture MS liquid medium and bridges were used in liquid to support the meristem and primary culture medium.

\subsection{Culture Technique}

Shoot tips of 25 - 30 day old potato plants of Diamant, Cardinal, Shilbilati and Lalpakri grown in the A.H.Z BIOTECH SEEDS Ltd. nursery were used as sources of meristems. The shoot tips were excised with the help of sharp blade and collected in a reagent bottle containing distilled water with few drops of savlon and few drops of tween-20 and quickly brought into the laboratory. Then the explants were washed for $2-3$ times with gradual change of sterile distilled water. The plant materials were transferred to a $250 \mathrm{~mL}$ sterilized conical flask. Surface sterilization was carried out by dipping the plant materials into $0.1 \%$ $\mathrm{HgCl}_{2}$ solution with gentle shaking for $2-8$ minutes followed by $3-5$ times washing with sterile distilled water in front of running laminar air flow cabinet.

\subsection{Isolation of Meristem and Culture}

Shoot tips of surface sterilized plant samples of four potato varieties were laid on the sterile tiles using sterile forceps. Immediately after dissection a single excised meristem was carefully placed on the " $M$ " shaped filter paper bridge within the culture tubes containing liquid MS medium (Figure 1). The neck of the tube was flamed with spirit lamp and then plugged. The inoculated culture tubes were incubated in a growth chamber providing a special culture environment. The cultures were maintained at $22^{\circ} \mathrm{C} \pm 2{ }^{\circ} \mathrm{C}$ with light intensity varied from 200 - 


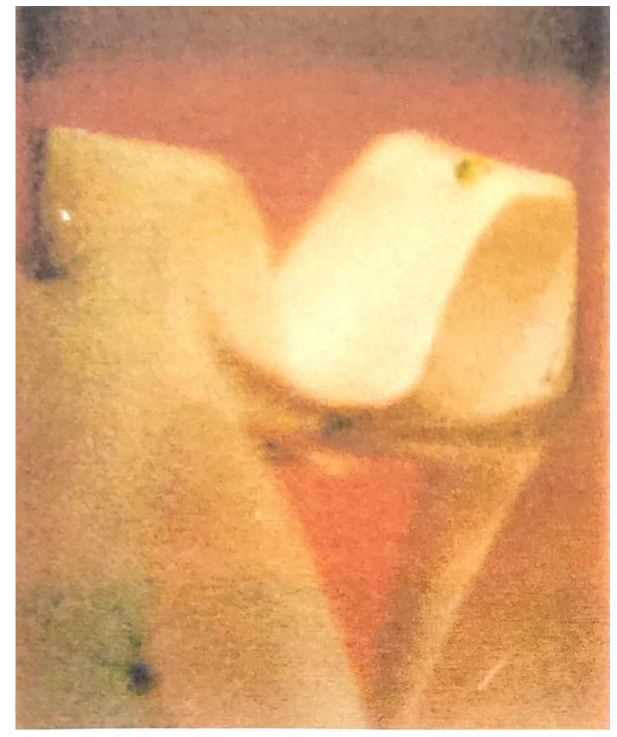

Figure 1. Development of meristem on filter paper bridge in liquid MS medium supplemented with $0.1 \mathrm{mg} / \mathrm{L} \mathrm{KIN}+0.5 \mathrm{mg} / \mathrm{L} \mathrm{GA}_{3}$ after 2, 4 and 6 weeks of culture respectively.

3000 lux. Generally the photoperiod was maintained giving 16 hours light and 8 hours dark. The culture tubes were checked daily to note the morphogenic response of cultured meristem.

Three to four weeks after primary culture, the explants those showed morphogenic response were removed aseptically from the culture tubes and transferred into tubes containing agar gelled MS medium supplemented with different growth regulators (Figure 2). After 30 - 35 day of culture initiation shoots were removed aseptically from the culture tubes and placed on a sterile tile and cut into convenient (basal end of the shoot) size and again transferred into test tubes containing different plant growth regulators supplemented in semisolid MS media.

When the generated shoots were $2-8 \mathrm{~cm}$ in height with $4-8$ leaves they were removed aseptically from the culture tubes (Figure 3 ) and placed on a sterilized Petridish, cut from the basal of the shoots using sharp scalpel. Then each base of the shoot was inoculated on freshly prepared semisolid MS medium supplemented with different combinations and concentrations of plant growth regulators for further shoot multiplication and root induction.

\subsection{Virus Indexing: ELISA Test}

The use of serological methods for rapid detection of plant viruses in vitro grown meristem-derived plantlets is popularly known as serodiagnosis [11] [12] [13]. Among the various serological methods so far developed, the double antibody sandwich enzyme-linked immuno-sorbent assay (DAS-ELISA) is extensively applied for its various merits over the other methods are reported by Clark and Bar-Joseph [14]. Different samples representing each symptom were tested 


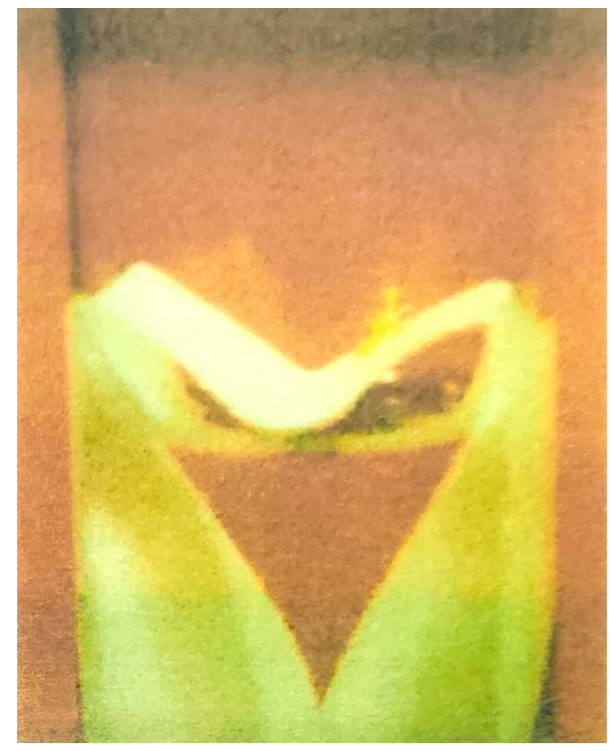

Figure 2. Development of meristem on filter paper bridge in liquid MS medium supplemented with $0.1 \mathrm{mg} / \mathrm{L} \mathrm{KIN}+0.5 \mathrm{mg} / \mathrm{L} \mathrm{GA}_{3}$ after 2, 4 and 6 weeks of culture respectively.

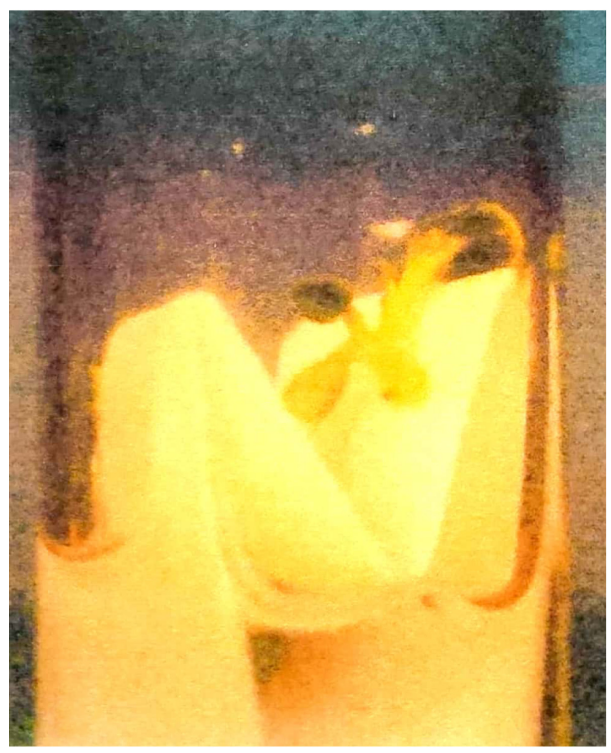

Figure 3. Development of meristem on filter paper bridge in liquid MS medium supplemented with $0.1 \mathrm{mg} / \mathrm{L} \mathrm{KIN}+0.5 \mathrm{mg} / \mathrm{L} \mathrm{GA}_{3}$ after 2, 4 and 6 weeks of culture respectively.

\section{by DAS-ELISA.}

\subsection{Micropropagation}

After 4 week of incubation when the plantlets attained a height of $7-9 \mathrm{~cm} \mathrm{mi}-$ cropropagation was started. The plantlets of four potato varieties identified as disease-free (checked by ELISA) were used for massive micropropagation. 
Nodal segments about 5 - $6 \mathrm{~mm}$ long was isolated from disease free plantlets having auxiliary bud (Figure 4). Isolated nodes were transferred into a $250 \mathrm{~mL}$ flasks or test tubes containing agar-solidified medium. Node cuttings were incubated at $22^{\circ} \mathrm{C} \pm 2^{\circ} \mathrm{C}$ with a 16 hours photoperiod. The developed plantlets were subculture as required after every 5 - 6 weeks (Figure 4).

\subsection{Acclimatization of in Vitro Grown Plantlets}

Well-rooted plantlets from meristem about $4-5 \mathrm{~cm}$ in height were ready for transplanting into soil. The plantlets grown inside the flask or test tubes were brought out from the growth chamber. After deplugging the culture tubes were kept in the room temperature for 4 - 5 days to bring them in contact to normal temperature. After 3 - 5 days of hardening the plantlets were taken out very carefully from the test tubes. The roots attached to the agar were gently and carefully washed out under running tap water.

\subsection{Field Evaluation/Field Establishment of Virus Free Plantlets}

After proper acclimatization of in vitro produced virus free plantlets of four potato varieties obtained from the meristem derived plantlets were planted on December, 2011 in the experimental field of Shyampur, Rajshahi covered with insect proof nylon net. The experiment was conducted following complete randomized design with three replications of each variety. The unit plots were $100 \times$ $40 \mathrm{~cm}$ in size which accommodated 30 plantlets at a spacing of $20 \times 10 \mathrm{~cm}$.

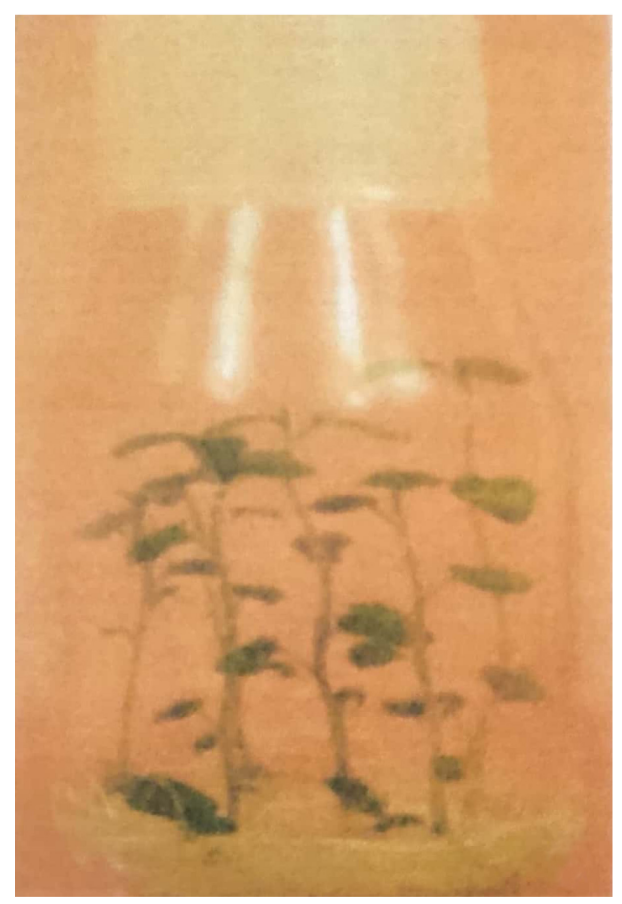

Figure 4. Plantlets grown through nod cutting on to MS medium supplemented with 0.5 $\mathrm{mg} / \mathrm{L} \mathrm{BA}+0.5 \mathrm{mg} / \mathrm{L} \mathrm{GA}_{3} 4$ weeks after culture. 
The plantlets were watered immediately after transplanting and the beds were provided with shades from 10 am to $3 \mathrm{pm}$ until the establishment of the plantlets into soil. The soil was prepared with cow dung and course sand (1:1 v/v), Urea, TSP and MP were applied at the rate of 75, 60 and $75 \mathrm{~kg} / \mathrm{ha}$. The entire does of TSP and MP and 50\% of Urea were applied at the time of land preparation. The rest $50 \%$ of Urea was applied as top dressing into two equal installments at 35 and 50 days after planting. The intercultural operations such as earthing up, weeding and mulching were done when needed. Fungicides and insecticides were applied to protect the crops. The experimental plots were irrigated frequently to maintain optimum soil moisture and also to keep the soil cool. The crop was harvested at maturity in the month of March, 2012 from the field within 90 - 100 days of its plantation.

\subsection{Data Collection}

Data from in vitro grown meristem-derived plantlets on percentage of regenerated plantlet, virus free plantlet, explants responded, and days to shoot initiation, number of shoots/explants and shoot length were recorded. Number of shoots/explants and shoot lengths were calculated after 28 days of culture. Percentage of explants responded was calculated using the following formula.

$$
\% \text { of explants responded }=\frac{\text { Number of explants responded }}{\text { Total number of explants cultured }} \times 100
$$

Data for field-grown plants on different characters were noted from the randomly selected 10 plants of each variety. The plantlets that survived in the field were expressed in percentage according to variety. Days to maturity was recorded when the leaves just began to die. Plant height, number of branches, leaves, tubers and tuber weight per plant, and percentage of tuber grades were recorded at the time of harvest. Weight of tubers was taken with a weighing balance. The harvested tubers were expressed in percentage and categorized in the following grades: 1) Grade A (<20 mm), 2) Grade B (20 - $30 \mathrm{~mm}), 3)$ Grade C (30 - 40 $\mathrm{mm})$, and 4) Grade D (>40 mm).

\subsection{Data Analysis}

Analysis of variance and subsequent significant test were done according to Gomez and Gomez, 1984. The mean values of all the parameters for four varieties were calculated and the analysis of variance was performed by "F" (variance ratio) test. The significance of differences among the treatment means were evaluated by least significant difference (LSD) test at 5\% level of probability [15] using MSTAT-C programme.

\section{Results}

\subsection{Genotypic Response of Four Potato Varieties in Meristem Culture}

Isolated meristems of four potato varieties Diamant, Cardinal, Shilbilati and 
Lalpakri were placed separately on " $M$ " shaped filter paper bridge in culture tubes $(125 \times 25 \mathrm{~mm})$ containing liquid MS medium supplemented with different concentrations and combinations of KIN and $\mathrm{GA}_{3}$ to find out varietal performance of four potato varieties (Figure 1). Data on days to response, percentage of meristems responded and morphogenic responses were recorded after 21 days of culture and are presented in Table 1.

Days to response ranged from 4 - 9 for all varieties with all four combinations. Among four combinations $0.1 \mathrm{mg} / \mathrm{L} \mathrm{KIN}+0.5 \mathrm{mg} / \mathrm{L} \mathrm{GA}_{3}$ showed better effect on the meristem culture. Cardinal showed the best response within the shortest duration of time taken $4-5$ days to grow in the media with $0.1 \mathrm{mg} / \mathrm{L} \mathrm{KIN}+0.5$ $\mathrm{mg} / \mathrm{L} \mathrm{GA}_{3}$ among four varieties.

Percentage of meristems responded to new growth ranged from $51 \%-78 \%$ in all four combinations of $\mathrm{KIN}$ and $\mathrm{GA}_{3}$ growth regulators with all potato varieties. The combination $0.1 \mathrm{mg} / \mathrm{L} \mathrm{KIN}+0.5 \mathrm{mg} / \mathrm{L} \mathrm{GA}_{3}$ exposed as the most appropriate for growth initiation for four potato varieties ranged from $56 \%-78 \%$ and responding the highest percentage of meristems recorded in Diamant (78\%) followed by Cardinal (73\%) and Lalpakri (61\%) where as the lowest was recorded in Shilbilati (56\%). The meristems of four potato varieties produced shoots and roots in all treatment combinations of KIN and $\mathrm{GA}_{3}$ except with the treatment

Table 1. Genotypic response of four potato varieties with four concentrations and combinations of $\mathrm{KIN}$ and $\mathrm{GA}_{3}$ in liquid MS medium on primary response of meristems.

\begin{tabular}{|c|c|c|c|c|c|}
\hline \multirow{2}{*}{$\begin{array}{l}\text { Plant growth } \\
\text { regulators } \\
(\mathrm{mg} / \mathrm{L})\end{array}$} & \multirow{2}{*}{ Variety } & \multirow{2}{*}{$\begin{array}{l}\text { Days to } \\
\text { response }\end{array}$} & \multirow{2}{*}{$\begin{array}{l}\text { \% of } \\
\text { meristems } \\
\text { responded }\end{array}$} & \multicolumn{2}{|c|}{ Morphogenic response } \\
\hline & & & & Shoot & Root \\
\hline \multirow[t]{4}{*}{$\mathrm{KIN} 0.1+\mathrm{GA}_{3} 0.1$} & Diamant & $5-6$ & 70 & + & + \\
\hline & Cardinal & $5-7$ & 68 & + & + \\
\hline & Shilbilati & $6-8$ & 70 & + & + \\
\hline & Lalpakri & $7-8$ & 72 & + & + \\
\hline \multirow[t]{4}{*}{$\mathrm{KIN} 0.1+\mathrm{GA}_{3} 0.5$} & Diamant & $5-6$ & 78 & + & + \\
\hline & Cardinal & $4-5$ & 73 & + & + \\
\hline & Shilbilati & $5-7$ & 56 & + & + \\
\hline & Lalpakri & $6-8$ & 61 & + & + \\
\hline \multirow[t]{4}{*}{$\mathrm{KIN} 0.5+\mathrm{GA}_{3} 0.1$} & Diamant & $5-7$ & 72 & + & + \\
\hline & Cardinal & $6-7$ & 61 & + & + \\
\hline & Shilbilati & $6-8$ & 51 & + & + \\
\hline & Lalpakri & $6-8$ & 56 & + & + \\
\hline \multirow[t]{4}{*}{$\mathrm{KIN} 0.5+\mathrm{GA}_{3} 0.5$} & Diamant & $6-8$ & 72 & + & + \\
\hline & Cardinal & $7-9$ & 64 & + & - \\
\hline & Shilbilati & $6-7$ & 56 & + & + \\
\hline & Lalpakri & $7-8$ & 66 & + & + \\
\hline LSD at $5 \%$ level & & & 5.76 & & \\
\hline
\end{tabular}

$+=$ Positive responses; - = Negative responses. 
$0.5 \mathrm{mg} / \mathrm{L} \mathrm{KIN}+0.5 \mathrm{mg} / \mathrm{L} \mathrm{GA}_{3}$ where Cardinal did not produce any root.

\subsection{DAS-ELISA Test for Virus Detection from Primary Established Meristem-Derived Plantlets}

Among the meristem-derived plantlets, a serological DAS-ELISA test was carried out to detect virus before micropropagation. No positive colour was found in the microliter plates when the in vitro grown meristem-derived plantlets were used as samples. In contrast, colour appeared when field-grown plants were used as samples that proved in vitro grown meristem-derived plantlets were free from the viruses.

\subsection{Genytopic Effect of Potato Varieties on Shoot Multiplication}

The nodal segments of the primary meristem-derived shoots developed from the isolated meristems of four potato varieties were cultured separately on to MS semisolid basal medium supplemented with BA, IBA, GA 3 and KIN in different combinations and concentrations. Data on days to shoot initiation, percentage of shoot formation, number of shoots/explant and shoot length $(\mathrm{cm})$ were recorded after 4 weeks of culture and are presented in Table 2.

Table 2. Genotypic response of four potato varieties with four concentrations and combinations of BA, IBA, GA 3 and KIN in MS medium on shoot multiplication from nodal segments of meristem-derived shoots.

\begin{tabular}{|c|c|c|c|c|c|}
\hline $\begin{array}{c}\text { Plant growth } \\
\text { regulators }(\mathrm{mg} / \mathrm{L})\end{array}$ & Variety & $\begin{array}{c}\text { Days to } \\
\text { shoot } \\
\text { initiation }\end{array}$ & $\begin{array}{c}\text { Percentage } \\
\text { of shoot } \\
\text { formation }\end{array}$ & $\begin{array}{l}\text { No. of } \\
\text { shoots/ } \\
\text { explant }\end{array}$ & $\begin{array}{l}\text { Length of } \\
\text { longest shoot } \\
(\mathrm{cm})\end{array}$ \\
\hline \multirow[t]{4}{*}{ BA $0.5+$ IBA 1.0} & Diamant & $7-9$ & 70 & 3.5 & 7.5 \\
\hline & Cardinal & $8-10$ & 72 & 3.1 & 7.1 \\
\hline & Shilbilati & $6-8$ & 56 & 3.2 & 8.1 \\
\hline & Lalpakri & $5-6$ & 65 & 3.5 & 6.5 \\
\hline \multirow[t]{4}{*}{$\mathrm{KIN} 0.1+\mathrm{GA}_{3} 0.1$} & Diamant & $6-8$ & 76 & 4.1 & 9.5 \\
\hline & Cardinal & $8-10$ & 68 & 4.2 & 9.7 \\
\hline & Shilbilati & $5-7$ & 66 & 3.6 & 8.2 \\
\hline & Lalpakri & $5-7$ & 68 & 3.0 & 6.8 \\
\hline \multirow[t]{4}{*}{ BA $0.5+\mathrm{GA}_{3} 0.5$} & Diamant & $5-7$ & 75 & 4.8 & 9.8 \\
\hline & Cardinal & $5-6$ & 76 & 4.4 & 9.7 \\
\hline & Shilbilati & $4-8$ & 66 & 3.2 & 9.0 \\
\hline & Lalpakri & $5-8$ & 60 & 3.3 & 7.8 \\
\hline \multirow[t]{4}{*}{$\mathrm{KIN} 0.5+\mathrm{GA}_{3} 0.5$} & Diamant & $8-10$ & 71 & 3.3 & 8.5 \\
\hline & Cardinal & $11-13$ & 70 & 3.1 & 9.2 \\
\hline & Shilbilati & $7-8$ & 60 & 2.8 & 8.6 \\
\hline & Lalpakri & $7-8$ & 68 & 3.0 & 7.9 \\
\hline LSD $5 \%$ level & & & 4.32 & 0.09 & NS \\
\hline
\end{tabular}

NS $=$ Non significant. 
Shoot multiplication from established meristems of four potato varieties were highly influenced by the four different combinations and concentrations of BA, IBA, $\mathrm{GA}_{3}$ and KIN. The cultured explants of four potato varieties initiated shoots within very short days ranged from 4 - 13 days. Among four combinations and concentrations, all potato varieties showed shorter duration of shoot initiation taking $4-8$ days in receiving the treatment $0.5 \mathrm{mg} / \mathrm{L} \mathrm{BA}+0.5 \mathrm{mg} / \mathrm{L}$ $\mathrm{GA}_{3}$. Among the varieties Cardinal exposed better response with this combination that required 5 - 6 days for shoot initiation followed by Diamant which required 5 - 7 days for the same.

Percentage of shoot proliferation was ranged from 56\% - 76\% among four potato varieties. All varieties showed better performance regarding percentage of shoot formation with the treatment $0.5 \mathrm{mg} / \mathrm{L} \mathrm{BA}+0.5 \mathrm{mg} / \mathrm{L} \mathrm{GA}$ and ranged from $60 \%-76 \%$ among four different combinations. The highest (76\%) nodal segments induced shoot proliferation was observed in Cardinal with this combination of growth regulator.

Number of shoots/explant of four varieties ranged from 2.8 - 4.8. The highest number of shoots/explant was recorded 4.8 in Diamant among all potato varieties with the treatment of $0.5 \mathrm{mg} / \mathrm{L} \mathrm{BA}+0.5 \mathrm{mg} / \mathrm{L} \mathrm{GA}_{3}$. The length of shoots of four potato varieties ranged from $6.5-9.8 \mathrm{~cm}$. The longest length $(9.8 \mathrm{~cm})$ of shoots was observed with the supplemented treatment medium of $0.5 \mathrm{mg} / \mathrm{L} \mathrm{BA}+$ $0.5 \mathrm{mg} / \mathrm{L} \mathrm{GA}_{3}$.

However, it was observed that genotypic traits of four varieties of potato were more or less same treated with all media formulations. The optimum response was exposed in the medium supplemented with the treatment $0.5 \mathrm{mg} / \mathrm{L} \mathrm{BA}+0.5$ $\mathrm{mg} / \mathrm{L} \mathrm{GA}_{3}$ for all potato varieties out of four media combinations. Diamant showed the highest response onto these PGR supplemented media among all varieties.

\subsection{Field Performance of in Vitro Produced Meristem-Derived Plantlets}

The data for field performance of in vitro produced meristem-derived plantlets were recorded on survival percentage of transplanted plantlets, days to tuber initiation (DTI), days to maturity (DM), plant height (PH), number of branches/plant $(\mathrm{NB})$, number of leaves/plant (NL), number of tubers/plant (NT), tuber weight/plant (TW) and tuber grade (\%), and the results are presented in Table 3 and Table 4. In vitro produced plantlets of all cultivars acclimated well in outdoor condition (Figure 4) and grew in the field normally up to maturity (Figure 5 and Figure 6).

The variety Cardinal showed the highest percentage (90\%) of plantlets survived in the field was closely followed by Diamant (85\%). The lowest survival rate was observed in the indigenous variety Lalpakri (62\%). Between the two indigenous varieties the highest survival rate $(70 \%)$ was found in Shilbilati (Table 3). 
Table 3. Field performance of plantlets of different potato varieties. Data were taken from 10 randomly selected plants of each replication.

\begin{tabular}{|c|c|c|c|c|c|c|c|c|}
\hline \multirow[b]{2}{*}{ Variety } & \multicolumn{8}{|c|}{ Different Parameters } \\
\hline & $\begin{array}{l}\text { Survival \% } \\
\text { of plantlets }\end{array}$ & DTI & DM & $\mathrm{PH}(\mathrm{cm})$ & NB & NL & NT & TW (g) \\
\hline Diamant & $85(2.26)$ & $\begin{array}{c}30.7 \\
(2.33)\end{array}$ & $\begin{array}{l}90.20 \\
(3.21)\end{array}$ & $\begin{array}{c}67.5 \\
(4.44)\end{array}$ & $\begin{array}{c}3.99 \\
(0.33)\end{array}$ & $\begin{array}{l}207.50 \\
(17.50)\end{array}$ & $\begin{array}{l}19.32 \\
(1.04)\end{array}$ & $\begin{array}{l}320.50 \\
(34.66)\end{array}$ \\
\hline Cardinal & $90(4.90)$ & $\begin{array}{c}29.0 \\
(1.24)\end{array}$ & $\begin{array}{l}93.53 \\
(4.40)\end{array}$ & $\begin{array}{c}60.2 \\
(1.07)\end{array}$ & $\begin{array}{c}4.50 \\
(0.15)\end{array}$ & $\begin{array}{l}240.30 \\
(11.56)\end{array}$ & $\begin{array}{l}21.50 \\
(2.20)\end{array}$ & $\begin{array}{l}343.40 \\
(33.33)\end{array}$ \\
\hline Shilibilati & $70(2.59)$ & $\begin{array}{c}32.8 \\
(7.67)\end{array}$ & $\begin{array}{l}99.20 \\
(8.44)\end{array}$ & $50.5(7.14)$ & $\begin{array}{c}7.48 \\
(0.33)\end{array}$ & $\begin{array}{l}170.50 \\
(3.56)\end{array}$ & $\begin{array}{l}27.52 \\
(1.20)\end{array}$ & $\begin{array}{l}180.35 \\
(10.33)\end{array}$ \\
\hline Lalpakri & $62(2.96)$ & $\begin{array}{l}35.2 \\
(3.0)\end{array}$ & $\begin{array}{l}105.42 \\
(4.29)\end{array}$ & $49.5(1.98)$ & $\begin{array}{c}3.45 \\
(0.44)\end{array}$ & $\begin{array}{l}151.30 \\
(5.79)\end{array}$ & $\begin{array}{l}24.60 \\
(2.30)\end{array}$ & $\begin{array}{l}102.30 \\
(3.33)\end{array}$ \\
\hline
\end{tabular}

Each value indicates the average of three (3) replications with standard deviation in parentheses. DTI = Days to tuber initiation, $\mathrm{DM}=$ Days to maturity, $\mathrm{PH}=$ Plant height, $\mathrm{NB}=$ Number of branches/plant, $\mathrm{NL}=$ Number of leaves/plant, NT $=$ Number of tubers/plant, TW $=$ Tuber weight/plant. The mean values were calculated from three replications.

Table 4. Tuber grade percentage of different potato varieties obtained from in vitro produced plantlets in the field.

\begin{tabular}{|c|c|c|c|c|}
\hline \multirow{2}{*}{ Variety } & \multicolumn{4}{|c|}{ Percentage of tuber grades } \\
\hline & $<20 \mathrm{~mm}$ & $20-30 \mathrm{~mm}$ & $30-40 \mathrm{~mm}$ & $>40 \mathrm{~mm}$ \\
\hline Diamant & - & $78(7.62)$ & $17(1.67)$ & $5(0.33)$ \\
\hline Cardinal & - & $79(10.29)$ & $15(3.31)$ & $6(1.13)$ \\
\hline Shilbilati & $68(4.93)$ & $18(1.44)$ & $14(2.67)$ & - \\
\hline Lalpakri & $76(5.66)$ & 19 (2.99) & $5(0.92)$ & - \\
\hline
\end{tabular}

Each value indicates the average of three (3) replications with standard deviation in parentheses.

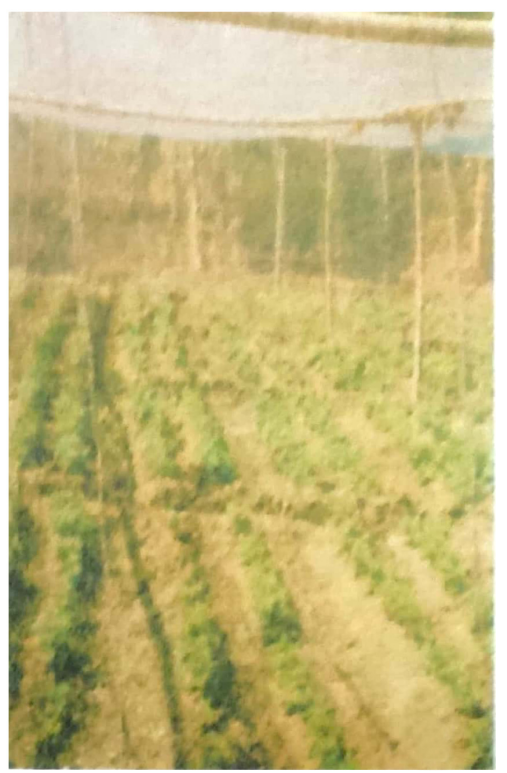

Figure 5. Transplanted plantlets in a net house, 3 weeks after plantation. 


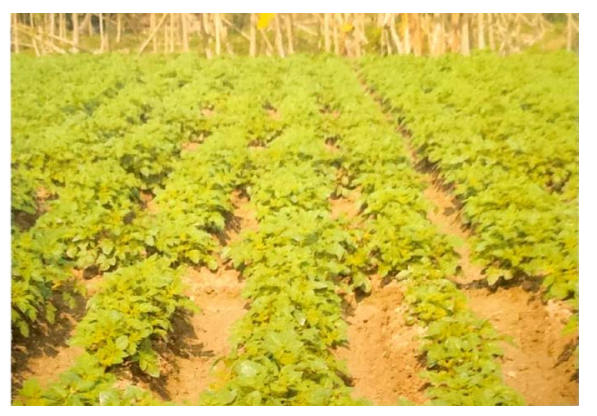

Figure 6. Healthy potato plants in the open field, 6 weeks after plantation.

The number of days required for tuber initiation varied with different varieties (Table 3). Lalpakri took the maximum days (35.20) which was statistically different from other varieties. Cardinal needed the shortest period (29.0 days) for tuber initiation. The maximum number of days (105.42) needed for maturity of the plant was recorded in Lalpakri that significantly differed from the rest of the varieties (Table 3), and closely followed by Shilbilati (99.42). The minimum number of day was required for maturity of the plants in Diamant (90.20) followed by Cardinal (93.53) and both differed from each other significantly.

In terms of plant height, Diamant attained the longest height $(67.50 \mathrm{~cm})$ (Table 3) that took minimum number of days to maturity and its height was significantly different from the rest of the varieties. The shortest height was recorded in Lalpakri $(49.50 \mathrm{~cm})$ that closely followed by Shilbilati $(50.50 \mathrm{~cm})$. The highest number of branches/plant was observed in Shilbilati (7.48), which was significantly higher than the rest of the varieties (Table 3 ). The lowest number of branches/plant was observed in Lalpakri (3.45) which was closely followed by Diamant (3.99) and Cardinal (4.50). The number of leaves/plant varied significantly with the varieties (Table 3 ). The highest number of leaves/plant was recorded in Cardinal (240.30) that differed significantly from other varieties and the second highest number was in Diamant (207.50). The lowest number of leaves/plant was found in Lalpakri (151.30) followed by Shilbilati (170.50).

Shilbilati produced the highest number of tuber per plant (27.52) followed by Lalpakri (24.60) and Cardinal (21.50) while the lowest number was recorded in Diamant (19.32) (Table 3). The greatest tuber weight/plant was obtained from Cardinal (343.40 g), which was significantly higher than those of the rest varieties (Table 3). The second highest tuber weight/plant was found in Diamant $(320.50 \mathrm{~g})$, and the lowest was recorded in Lalpakri (102.30 g).

The results on tuber grade classified on the basis of different sizes are presented in Table 4. It was observed that the two high yielding exotic varieties Cardinal and Diamant always produced tubers more than $20 \mathrm{~mm}$ in size. Lalpakri produced the highest $(76 \%)$ percentage of tubers of this grade.

Significantly higher percentage of tubers of $20-30 \mathrm{~mm}$ in size was recorded in the exotic variety Cardinal (79\%) which was identically similar to Diamant (78\%). In contrast, the indigenous varieties Shilbilati and Lalpakri produced the 
same grade $(20-30 \mathrm{~mm})$ of tubers those were significantly lower at $18 \%$ and $19 \%$ respectively. In the case of $30-40 \mathrm{~mm}$ size the highest percentage was observed in Diamant (17\%) followed by Cardinal (15\%) while the lowest percentage in this grade was observed in Lalpakri (5\%).

The indigenous varieties Shilbilati and Lalpakri failed to produce tubers greater than $40 \mathrm{~mm}$ in size and only the high yielding varieties produced tubers of this grade. The highest percentage of tuber in this grade was observed in Cardinal (6\%) followed by Diamant (5\%) and these were identically similar to each other.

\section{Discussion}

The causes of low production and non-profitability of potato cultivation might be due to lack of quality seeds of good varieties, unavailability and uneven distribution of certified seeds, inadequate storage facilities, high production cost, and short growing season are noticeable [7].

Potato is usually vegetatively propagated and very much susceptible to a number of viral diseases, which causes remarkable decrease in yield. However, meristem culture is one of the important methods to produce virus-free stock plants [16] [17] [18]. The shoots of an apical meristem and the first set of primordial leaves are generally not connected to the vascular system of the plant and therefore, are not contaminated with viruses that travel through the vascular system [19] [20]. If the explant is carefully excised so as not to contaminate it with sap from more mature leaves or stem tissues and it is placed in culture tube a virus-free plant can be established.

The size of the meristem explant is critical for virus eradication. Often, so-called meristem tip cultures have failed to eliminate virus infection because the explant contains shoot apices with vascular tissue instead of true meristem [20] [21]. The technique, combined with heat treatment (thermotherapy) or chemical treatment (chemotherapy) was proved to be very effective in virus eradication [22] [23]. Commercial production of virus-free seed potatoes through meristem culture has been a regular practice in many developed countries. DAS-ELISA methods conclusively proved that PVX, PVY and PLRV viruses were not present in the meristem-derived plantlets. Many researchers used this popular serological detection method for identification of different kinds of viruses in different crops [11] [12] [24].

In the present investigation meristems were isolated from 25 - 30 day old field-grown potato plant from Diamant, Cardinal, Shilbilati and Lalpakri varieties, and cultured on MS liquid media with different types of plant growth regulators viz. $\mathrm{BA}, \mathrm{KIN}, \mathrm{NAA}, \mathrm{IAA}, \mathrm{GA}_{3}$ at their different combinations for the establishment of primary meristem culture. For primary establishment of meristem, liquid MS medium with Filter Paper Bridge was used. Many workers got satisfactory results with MS liquid medium in different crops [25]-[36]. Various concentrations and combinations of plant growth regulators remarkably influ- 
enced in resuming growth of meristem. Among the various concentrations of plant growth regulators $\mathrm{KIN}$ and $\mathrm{GA}_{3}$ combination at a concentration ranging from $0.1 \mathrm{mg} / \mathrm{L}$ to $0.5 \mathrm{mg} / \mathrm{L}$ were used for assessing the optimum concentration (Table 1). Out of different treatments MS medium fortified with $0.1 \mathrm{mg} / \mathrm{L} \mathrm{KIN}$ $+0.5 \mathrm{mg} / \mathrm{L} \mathrm{GA}_{3}$ was found to be the most effective in increasing the growth of meristems. Cultured meristems showed quick responses ( 4 - 5 days) without any formation of callus at the base of the explant. Ahmmed [37] used same growth regulator formulation and obtained satisfactory results for the establishment of meristem culture in potato. Mohammad [38] also found the similar results in potato. Table 1 exposed that more or less all four varieties responded equally with all concentrations and combinations of $\mathrm{KIN}$ and $\mathrm{GA}_{3}$. The differences found in different varieties were statistically non-significant. All the varieties showed brilliant performances with $0.1 \mathrm{mg} / \mathrm{L} \mathrm{KIN}+0.5 \mathrm{mg} / \mathrm{L} \mathrm{GA}$. All potato varieties showed shoot and root initiation by using all the combinations and concentrations. Except in $\mathrm{KIN} 0.5 \mathrm{mg} / \mathrm{L}+\mathrm{GA}_{3} 0.5 \mathrm{mg} / \mathrm{L}$ where Cardinal failed to initiate root. Ahmmed [39] also used same growth regulator formulation and obtained satisfactory result for establishment of primary meristem culture in potato. Mohammad [38] and Rahman [20] also found similar results for genotypic response of potato varieties. Again, Quack [39] postulated that the absence of vascular elements in the meristem is a possible reason as why the virus concentration is low in meristem.

For shoot multiplication established meristems were subcultured on to MS semisolid media supplemented with different concentrations of auxin, cytokinin and gibberellic acid at their different combination in order to find out suitable growth regulator formulation for maximum shoot production. Among the treatment combinations, $\mathrm{BA}$ and $\mathrm{GA}_{3}$ combination showed the best performance for shoot multiplication. The results demonstrated that the highest number of shoots/explant and the longest shoot were recorded with the media combination $0.5 \mathrm{mg} / \mathrm{L} \mathrm{BA}+0.5 \mathrm{mg} / \mathrm{L} \mathrm{GA}_{3}$ (Table 4). Many earlier workers also got satisfactory results in potato crops with the combination of $\mathrm{mg} / \mathrm{L} \mathrm{BA}$ and $\mathrm{mg} / \mathrm{L} \mathrm{GA}_{3}$ [40] [41] [42] [43] [44]. The results of this experiment proved that four varieties showed more or less equal performance with all combinations and concentrations of BA, IBA, GA3 and KIN. All varieties showed brilliant performance in the media with $0.5 \mathrm{mg} / \mathrm{L} \mathrm{BA}+0.5 \mathrm{mg} / \mathrm{L} \mathrm{GA}_{3}$ for multiple shoot proliferation. Siddique [41], Miller et al. [42], Hussey and Stacy [45], and Ahsan et al. [18] also found that different varieties of potato performed well in the media with 0.5 $\mathrm{mg} / \mathrm{L} \mathrm{BA}+0.5 \mathrm{mg} / \mathrm{L} \mathrm{GA}_{3}$. Use of $\mathrm{GA}_{3}$ and BA for adventitious shoot development has also been reported by Marani and Pisi [46], and Evans et al. [47]. The varieties Dimant and Cardinal were more responsive for massive micro propagation of plantlets than Shilbilati and Lalpakri (Table 2).

During the field experiment in the present study it was closely observed that the in vitro produced plantlets having relatively thicker and harder stem at the time of transplanting had a higher survival rate than the less thicker and harder 
one. The high yielding varieties gave rise to harder in vitro plantlets. The survival rate was higher in the exotic varieties (Cardinal 90\% and Diamant $85 \%$ ) than the indigenous varieties (Shilbilati 70\% and Lalpakri 62\%) in the field (Table 3). From visual observation of the plants no symptom of viral diseases was noticed. Generally the indigenous varieties took longer time for tuberization than the high yielding exotic varieties. This agrees nicely to Siddique's [48] results who reported that longer time was needed for tuber initiation in the indigenous varieties than the exotic ones under the climatic condition of Bangladesh. Longer time "as needed for maturity of the indigenous varieties than the high yielding varieties", agrees with Siddique and Rashid [49] who mentioned that the indigenous varieties have a long growth cycle than the modern varieties under the climatic condition of Bangladesh.

The highest number of branches/plant was observed in Shilbilati, which was significantly higher than the rest of the varieties. The remaining three varieties were not differing much from one another. This finding did not agree with results of Hossain [50] probably due to different sets of varieties and different composition of the culture media used for the two studies. The number of leaves/plant varied with the variety. The highest number of leaves/plant was observed in Cardinal followed by Diamant that differed significantly than the indigenous varieties. This result agrees with the findings of Hossain [50]. It was also observed that the high yielding varieties produced higher weight of tuber/plant compared to those of the indigenous varieties though the tuber numbers/plant was higher in the indigenous varieties. Cardinal produced significantly highest amount of tuber weight per plant (343.40 g) followed by Diamant $(320.50 \mathrm{~g})$ and the lowest was obtained from Lalpakri $(102.30 \mathrm{~g})$. It is a common phenomenon that the indigenous varieties produce numerous sized tubers than the high yielding varieties. The high yielding varieties Cardinal and Diamant produced tubers greater than $20 \mathrm{~mm}$ in size. Lalpakri produced the highest percentage of tubers in this grade $(<20 \mathrm{~mm})$, while significantly higher percentage of tuber of $20-30 \mathrm{~mm}$ size were recorded in the exotic varieties. The highest percentage of tuber grade at $>40 \mathrm{~mm}$ in size was observed in Cardinal (6\%) followed by Diamant (5\%) whereas no tuber was produced as the size of this grade in the indigenous varieties.

\section{Conclusion}

Among the combinations of different growth regulators the treatment $0.1 \mathrm{mg} / \mathrm{L}$ $\mathrm{KIN}+0.5 \mathrm{mg} / \mathrm{L} \mathrm{GA}_{3}$ was found to be the best for the primary establishment of meristem culture, and the treatment with $0.5 \mathrm{mg} / \mathrm{L} \mathrm{BA}+0.5 \mathrm{mg} / \mathrm{L} \mathrm{GA}_{3}$ was found to be the best for shoot proliferation. Diamant exposed a higher frequency of shoot proliferation out of the four cultivars of potato (Diamant, Cardinal, Shilbilati and Lalpakri). Observation from the results of the field study of in vitro meristem-derived plantlets that the virus-free indigenous potato varieties produced plants of normal height and the exotic varieties were much superior to the 
indigenous varieties. The indigenous varieties produced higher plants but smaller tubers/plant compared to those of the exotic varieties.

\section{Conflicts of Interest}

The authors declare no conflicts of interest regarding the publication of this paper.

\section{References}

[1] Struik, P.C. and Wiersema, S.G. (1999) Seed Potato Technology. Wageningen Press, Wageningen. https://doi.org/10.3920/978-90-8686-759-2

[2] BBS (2011) Vegetables Production Statistics, 2011. Bangladesh Bureau of Statistics, Dhaka.

[3] BBS (2012) Statistical Year Book of Bangladesh. Bangladesh Statistics Division, Ministry of Planning, Govt. of the People's Republic of Bangladesh, Bangladesh Bureau of Statistics, Dhaka.

[4] Anonymous (2008) International Year of the World Potato Production. http://www.potato2008.org/en/world/

[5] Chowdhury, M.A.H. and Hasan, M.S. (2013) Handbook of Agricultural Technology. Bangladesh Agricultural Research Council, Farmgate, Dhaka, 230.

[6] Islam, R. and Alsadon, A.A. (2003) Successful Application of Biotechnology in Potato: A Review Paper. Bangladesh Journal of Genetics and Biotechnology, 4, 1-6.

[7] Khan, M.S., Timmermann, C., Hoque, M.I., Sarker, R.H. and Mühlbach, H.-P. (2009) Detection of Potato Spindle Tuber Viroid (PSTVd) in Minute Amounts of Potato (Solanum tuberosum L.) Leaf Tissue by Hybridization Techniques and, Together with Potato Viruses, by Multiplex RT-PCR. Journal of Plant Diseases and Protection, 16, 97-105. https://doi.org/10.1007/BF03356293

[8] Ahmed, K.U. (1981) Potato Research in Bangladesh. Potato Research Centre. BARI, Joydebpur, Gazipur, p. 52.

[9] Morel, G. and Marthin, C. (1955) Guerison de pommes de terre atteinties de maladies a. virus. CR Séances Acad AgricFr, 41, 472-475.

[10] Murashige, T. and Skoog, F. (1962) A Revised Medium for Rapid Growth and Bioassays with Tobacco Tissue Cultures. Physiologia Plantarum, 15, 473-497. https://doi.org/10.1111/j.1399-3054.1962.tb08052.x

[11] Akanda, A.M., Tsuno, K. and Wakimoto, S. (1991) Serological Detection of Four Plant Viruses in Cucurbitaceous Craps in Bangladesh. Japanese Journal of Phytopathology, 57, 499-505. https://doi.org/10.3186/jjphytopath.57.499

[12] Akanda, A.M., Tsuno, K. and Wakimoto, S. (1991) Serodiagnosis of Viruses Infecting Some Crops of Bangladesh. Journal-Faculty of Agriculture Kyushu University, Japan, 35, 151-159.

[13] Van Regenmortel, M.H.V. (1978) Application of Plant Virus Serology. Annual Review of Phytopathology, 12, 207-271. https://doi.org/10.1146/annurev.py.16.090178.000421

[14] Clark, M.F. and Bar-Joseph, M. (1984) Enzyme Immunosorbent Assays in Plant Virology. Methods in Virology, 7, 51-85. https://doi.org/10.1016/B978-0-12-470207-3.50009-7

[15] Gomez, K.A. and Gomez, A.A. (1984) Statistical Procedure for Agricultural Re- 
search. 2nd Edition, International Rice Research Institute, Los Baños, 97-116.

[16] Morel, G. and Marthin, C. (1952) Guerison de Dahlias attaints d'une maladie a. virus. CR Hebd Séances Acad, 253, 1324-1325.

[17] Martin, C.M. and Vernoy, C.R. (1955) La Multiplication Vegetative in Vitro des vegetaux ligneu cultivers: Casdes Resiens. Comptes Rendus de l'Académie des Sciences, 293, 175-177.

[18] Ahsan, N., Hossain, S.A., Alam, M.F., Hossain, M.M., Islam, R. and Sultana, K.S. (2003) Virus Free Potato Tuber Seed Production through Meristem Culture in Tropical Asia. Asian Journal of Plant Sciences, 2, 616-622. https://doi.org/10.3923/ajps.2003.616.622

[19] Parkash, J. and Picrik, R.L.M. (1993) Plant Biotechnology: Commercial Prospects and Problems. Oxford and IBH Publishing Co. Pvt. Ltd., New Delhi, 113-114.

[20] Rahman, B.M. (1998) Meristem Culture and Production of Virus Free Clones in Bitter Gourd. M.Sc. Thesis, Plant Breeding Laboratory, Department of Botany, Rajshahi University, Rajshahi.

[21] Adams, A.N. (1975) Elimination of Virus from the Hop (Humulus lupulus) by Heat Therapy and Meristem Culture. Journal of Horticultural Science, 50, 151-160. https://doi.org/10.1080/00221589.1975.11514616

[22] De, K.K. (1992) An Introduction to Plant Tissue Culture. Now Central Book Agency, Calcutta, 167-168.

[23] Towill, L.E. (1981) Survival at Low Temperatures of Shoot-Tips from Cultivars of Solanum tuberosum Group Tuberosum. Cryo-Letters, 2, 373-382.

[24] Alam, M.N. (1995) Studies on the Virus Diseases of Tomato in Bangladesh. M. Phill. Thesis, Department of Botany, Jahangirnagar University, Dhaka.

[25] White, P.R. (1943) A Handbook of Plant Tissue Culture, Jaques catell, Lancaster. Plant Physiology, 9, 585-600. https://doi.org/10.1104/pp.9.3.585

[26] White, P.R. (1968) Potential Unlimited Growth of Excised Tomato Root Tips in a Liquid Medium. Plant Physiology, 9, 585-600. https://doi.org/10.1104/pp.9.3.585

[27] White, P.R. (1943) A Handbook of Plant Tissue Culture. The Jaques Cattell Press, Lancaster, 277 p.

[28] Stone, O.M. (1963) Factors Affecting the Growth of Carnation Plants from Shoot Apices. Annals of Applied Biology, 52, 199-209. https://doi.org/10.1111/j.1744-7348.1963.tb03743.x

[29] Goodwin, P.B. (1966) An Improved Medium for the Rapid Propagation of Isolated Potato Buds. Journal of Experimental Botany, 17, 590-595.

https://doi.org/10.1093/jxb/17.3.590

[30] Vine, S.J. (1968) Improved Culture of Apical Tissues for Production of Virus-Free Strawberries. Journal of Horticultural Science, 43, 293-297.

https://doi.org/10.1080/00221589.1968.11514257

[31] Pennazion, S. and Redolfi, P. (1973) Factors Affecting the Cultures in Vitro of Potato Meristem Tips. Potato Research, 16, 20-29. https://doi.org/10.1007/BF02360589

[32] Ali, A.M. (1998) Meristem culture for virus-free plant production Abelomschus esculentus (L.) Mocnch, M.Sc. Thesis, Breeding Laboratory, Botany Dept. Rajshahi University.

[33] Steward, F.C., Mapes, M.O. and Ammirato, P.V. (1969) Chapter 8. Growth and Morphogenesis in Tissues and Green Cell Culture. In: Treatise, A., Ed., Plant Physi- 
ology, Academic Press, New York, 329-376. https://doi.org/10.1016/B978-0-12-395679-8.50014-5

[34] Walkey, D.G.A. (1986) The Production of Virus Free Tuber by Apical Tip Culture. Journal of Horticultural Science, 43, 283-287. https://doi.org/10.1080/00221589.1968.11514255

[35] Yee, S., Stevens, B., Coleman, S., Scabrook, J.E.A. and Li, X.-Q. (2001) High Efficiency Regeneration in Vitro from Potato Petioles with Intact Leaflets. American Journal of Potato Research, 78, 151-157. https://doi.org/10.1007/BF02874770

[36] Alam, M.F., Ahsan, N., Hossain, S.A., Anisuzzaman, M., Parvcz, S., Swaraz, A.M. and Khan, M.R. (2003) Effect of Different Sources and Concentrations of Cenrbon on in Vitro Tuberization in Potato (Solanum tuberosum L.) cv. Diamant. Bangladesh Journal of Genetics and Biotechnology, 4, 42-48.

[37] Ahmmed, S.K. (1999) Production of Virus Free Clone through Meristem Culture of Solanum tuberosum L. M.Sc. Thesis, Plant Breeding Lab. Genetics and Breeding Department, Rajshhai University, Rajshahi.

[38] Mohammad, K.D. (2002) Improvement of Potato (Solanum tuberosum L.) through in Vitro Culture. M. Phil. Thesis, Department of Botany, Rajshahi University, Rajshahi.

[39] Quack, F. (1977) Meristem Culture and Virus-Free Plants. In: Reinert, J. and Bajaj, Y.P.S., Eds, Applied and Fundamental Aspects of Plant Cell, Tissue, and Organ Culture. Springer Verlag, Berlin, 598-615.

[40] Kassanis, B. (1957) The Use of Tissues Culture to Produce Virus Free Clones from Infected Potato Varieties. Annals of Applied Biology, 45, 422-427. https://doi.org/10.1111/j.1744-7348.1957.tb05879.x

[41] Siddique, M.A. (1991) Production of Indigenous Potato Varieties in Bangladesh. In: Proceedings of Symposium on the Role of Novel and Traditional and Seed Potato Production Techniques in Asia, Asian Potato Association, Bandung, 4-8.

[42] Miller, P.R., Amirouhe, L., Stuchbury, T. and Mathews, S. (1985) The Use of Plant Growth Regulators in Micro Propagation of Slow-Growing Potato Cultivars. Potato Research, 28, 479-486. https://doi.org/10.1007/BF02357526

[43] Mondal, A.A. (2002) Improvement of Potato (Solanum tuberosum L.) through Hybridization and in Vitro Technique. Ph.D. Thesis, Institute of Biological Sciences, Rajshahi University, Rajshahi.

[44] Khatun, N. (2004) Micro Propagation and Genetic Transformation in Potato (Solanum tuberosum L.). Ph.D. Thesis, Institute of Biological Sciences, Rajshahi University, Rajshahi.

[45] Hussey, G. and Stacey, N.J. (1981) In Vitro Propagation of Potato (Solanum tuberosum L.). Annals of Botany, 48, 787-796.

https://doi.org/10.1093/oxfordjournals.aob.a086186

[46] Marani, F. and Pisi, A. (1977) Meristem-Tip Culture and Vegetative Propagation in Potato. Acta Horticulturae, 78, 414-415.

https://doi.org/10.17660/ActaHortic.1977.78.52

[47] Evans, D.A., Sharp, W.R. and Medina-Fillho, H.P. (1984) Somaclona and Gametoclonal Variation. American Journal of Botany, 71, 759-774. https://doi.org/10.1002/j.1537-2197.1984.tb14141.x

[48] Siddique, M.A. (1989) A Report on the Improvement of Indigenous Potato Varieties of Bangladesh. Department of Horticulture, Bangladesh Agricultural University, Mymensingh, 57. 
[49] Siddique, M.A. and Rashid, M.M. (1990) Scope for Increasing the Yield of Indigenous Potato Varieties of Bangladesh. In: Seed Potato of Bangladesh, Proceedings of International Seminar on Seed Potato, BADC, Dhaka, 160-171.

[50] Hossain, M.J. (1991) Field Performance of Some Indigenous Potato Varieties after Cleaning from Viruses through Meristem Culture. Thai Journal of Agricultural Science, 24, 57-66. 